\title{
CORPORATE SOCIAL RESPONSIBILITY IMPLEMENTATION STRATEGIES DURING THE COVID-19 PANDEMIC
}

\author{
Hendi PRIHANTO ${ }^{1 *}$, Hermiyetti HERMIYETTI ${ }^{2}$, Nirwan MULYATNO $^{3}$ \\ ${ }^{1,3}$ Department of Accounting, Faculty of Economics, Universitas Prof.Dr.Moestopo (Beragama); \\ ${ }^{2}$ Department of Accounting, Faculty of Economics and Science, Bakrie University, \\ *hendiprihanto@dsn.moestopo.ac.id
}

\begin{abstract}
The COVID-19 pandemic has had a significant impact not only on the industrial sector, the economy, but also on services in the education sector. Various communication and media barriers in the delivery of learning, make many students experience setbacks in understanding the learning that should be obtained. For this reason, community service carried out aims to provide understanding to students in particular, and the general public to understand the knowledge of the company's obligations to the community. The delivery method is used using the Zoom online application which is followed by various students, lecturers from various campuses and communities from various regions. The results of the activity show that many of the students, and the public do not understand the concept of corporate social responsibility. Through the PKM activities carried out, it has an impact on increasing the understanding and knowledge of the participants about social responsibility
\end{abstract}

Keywords: Pandemic, Covid 19, Companies, CSR, Students, Lecturers and Society

\section{BACKGROUND}

The current industrial era contributes a lot to environmental damage in order to satisfy the desire of corporations to achieve maximum profit. The concept of sustainable development in the business world is no longer only faced with responsibilities that are based on a single bottom line (SBL), or just increasing the value of the company (corporate value) which is seen from the aspect of its economic (financial) condition. However, it is based on the triple bottom line (TBL) concept, namely the synergy between the three elements which include economic, social, and environmental or better known as the 3Ps (Profit, People and Planet) (Elkington, 1997). This is so that the company prepares three different bottom lines and makes them quite separate, namely on the scope of profit, people account, and planet which is translated as follows :

1. Profit is a financial measure of a company's profit and loss

2. People account is an actualization for the company in various forms of a company's social responsibility for its activities

3. Planet is a measure of how responsible a company is to the environment in which it lives

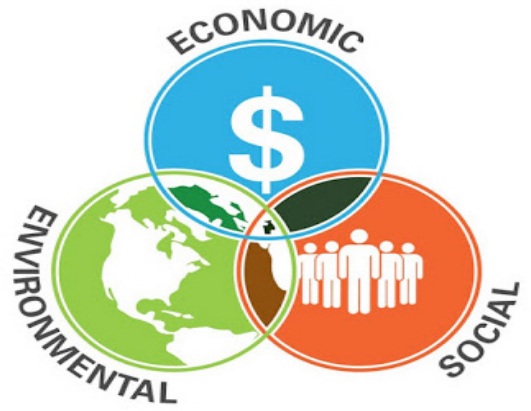

Figure 1. CSR Concept

The Covid 19 or Corona virus pandemic was first recognized and emerged as an outbreak when it first occurred on December 31,2019, which was marked by the emergence of this deadly virus in China, an outbreak appeared in a port city around Wuhan. This epidemic then spread very quickly to various countries in the next two weeks, so that it became a global pandemic and finally arrived in Indonesia and was finally designated by the government as a national disaster on Saturday 14 March 2020 and Indonesia entered a nonnatural disaster emergency period (https://feb.unpad.ac.id/ dampak-pandemi-corona-terhadap-laporan-keuangan-dan-

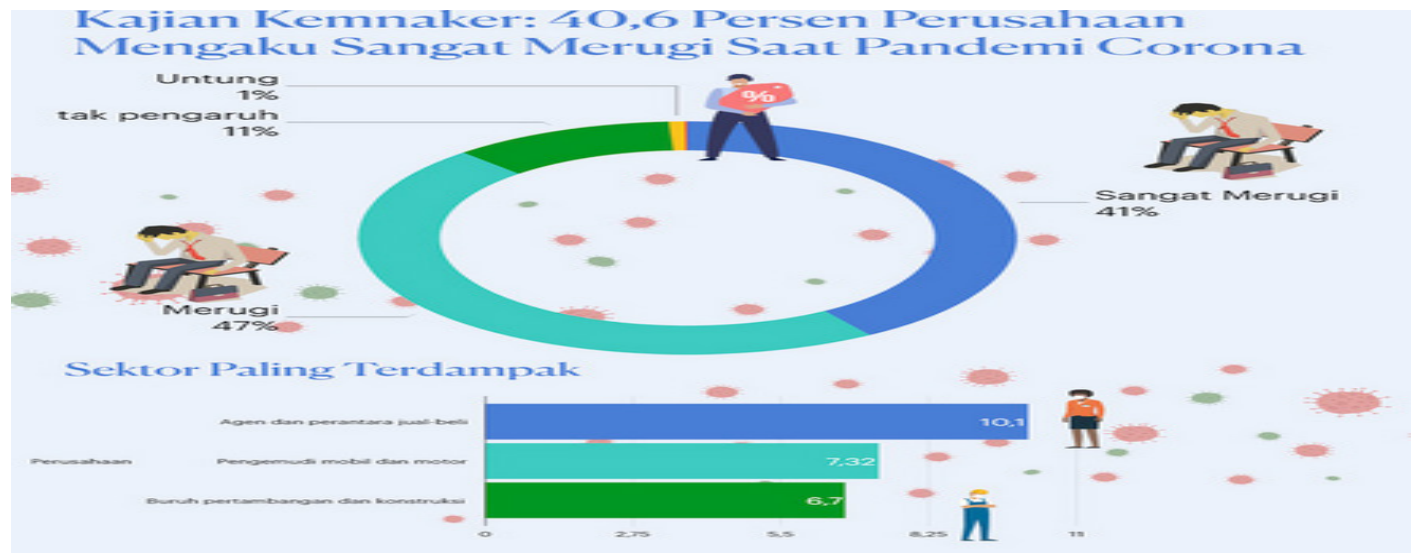

Picture 2. Efect Pandemic Covid 19

Source:https://www.merdeka.com/peristiwa/infografis-dampak-pandemi-covid-19-terhadap-perusahaan.html 
praktik-bisnis-di-indonesia/, diakses 25-01-2021 ). During the pandemic, a number of conditions in the business and economic sectors were affected and became problems that resulted in a decline in business activities and slumped, even a number of corporations experienced closure or experienced financial distress and were unable to survive.

This pandemic outbreak has caused a number of losses, even the bankruptcy of a number of businesses on a large and small scale, so that this situation makes it possible for companies to find it difficult to carry out their CSR and become constrained, especially the implementation of CSR is currently still experiencing pros and cons in its understanding by the company (Prihanto, 2018). However, not all companies are affected by this pandemic, there are also companies that actually gain profits and make their capital grow bigger with the Covid 19 pandemic, so that they do not experience problems in implementing their CSR, but instead should provide opportunities for them to do CSR, such as telecommunications and IT (information technology) companies.

This data has been proven and confirmed in the results of a study by the Employment Planning and Development Agency (Barenbang Naker) which stated that as many as 40.6 percent of respondents admitted that their company was in great loss during the Covid-19 pandemic, while 47.4 percent of respondents said they had lost. The longer the pandemic has been going on, many large, medium and small companies have closed their businesses. This activity is carried out with the aim of providing insight to the public, and academics in providing knowledge on the emergence of opportunities for business ideas as well as taking care of social and environmental concerns, with the current state of the economic crisis. The activity also aims to provide education and opportunities to help each other during the pandemic to produce positive activities with the current situation and conditions.

\section{METHOD}

\section{Time and Executor}

This activity was held on Saturday, January 16, 2021 at 10.00 - 12.00 wib using Zoom (online) media which was attended by students with a total of 147 general public, practitioners, and students from various universities such as Universitas Prof.Dr.Moestopo (Beragama), Universitas Bakri, Universitas Paramadina, Universitas Mercu Buana, IBI Kosgoro 1957, Universitas Dian Nusantara dan Universitas Bung Karno. The implementation of this activity also uses the Lecture approach and FGD (Focus Group Discussion) which explores an issue or a special phenomenon formed from the discussion of a group or individual that focuses on joint activities among the individuals involved in it to produce a conclusion on a common understanding (Kitzinger, 1999). Participants can ask questions which are then answered or discussed by the resource person on the problems, ignorance or curiosity of the participants about CSR and its implementation.

\section{RESULTS AND DISCUSSION}

The implementation of CSR when it has become a necessity and cannot be postponed further, this is because it is related to the ethical behavior of the company as an institution and organization that contributes greatly to the environmental damage that is currently happening. Companies and industries that are currently growing rapidly contribute about $70 \%$ of the damage to the surrounding environment. However, not all CSR implementation can run as expected, this factor is due to the different conditions that occur in companies and each country. Developed countries are generally more understanding and have a higher level of awareness than developing countries, as is the case with the concept of CSR that was born in the 1970s which was popularized in the book Cannibals With Forks: The Triple Bottom Line in 21st Century Business (Elkington, 1997).

The development of CSR in Indonesia began in the 1980s which then became increasingly popular and developed since the 1990s where it is marked by the history of the emergence of CSR in the world. Some of the activities carried out related to CSR are: natural disaster assistance, distribution of holiday allowances (THR), scholarships and other activities that are not intended for profit. After 2007 the obligation regarding CSR was also included in Law Number 40 of 2007 which contains the obligation of a Limited Liability Company to exit, thus most Indonesian companies have carried out CSR programs even though these activities are sometimes still limited to seeking popularity, elevating the company's image, and engagement. government regulations.

Some people believe that the company doing CSR will increase the value of the company, so that the CSR concept develops and becomes more and more a lesson not only for practitioners, but also for academics who make various CSR implementation concepts as shown below.

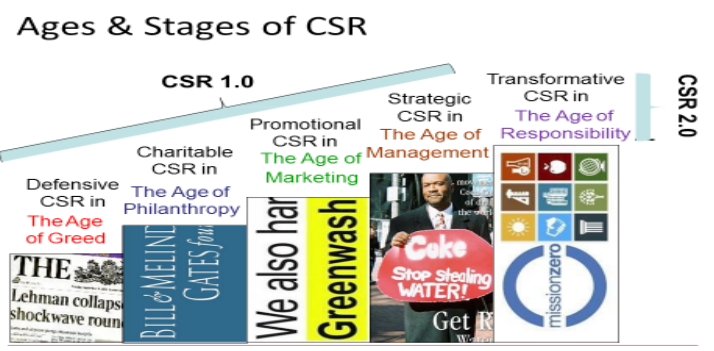

Figure 3. Development of CSR concept

Along with the times, the implementation of CSR has become an activity that has received a lot of public attention, not only on how to carry out and describe these activities, However, CSR also provides space for new professions and jobs (Hardum, 2014) that develop in handling activities, strategies, reporting (disclosure) or audits of reported activities. Community service activities carried out at this time are the result of the accumulation of requests from various internal and external parties to the 
FEB UPDM Community Service Team (B), to provide socialization, direction and understanding of the CSR concept and its implementation.

Public interest in CSR can provide an indication that the public has an awareness of environmental awareness, considering that so far many corporate behaviors are solely exploiting the environment, in carrying out its production operations pollute the environment (water, soil, air) market products in a way that is not environmentally friendly, and the products produced make waste that disrupts natural sustainability (Welianto, 2020). The attention and participation of the PKM activity participants can be seen through the zoom taken from the screenshot and presented in the following figure 3 .

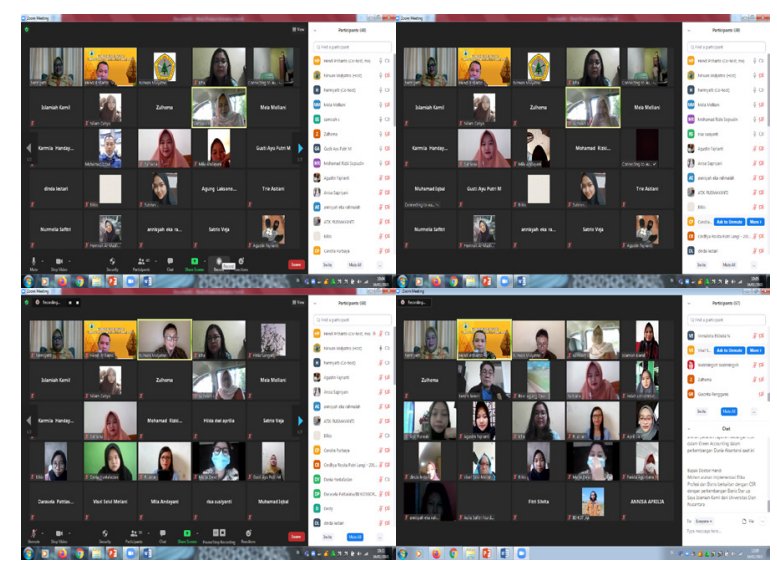

Figure 3. Community Service Participants

CSR also provides many benefits not only for the community but also for the companies that do it. For the community, CSR can provide added value in improving their economy, such as empowering community businesses through MSMEs, cooperatives and so on. CSR can also provide an increase in public knowledge with scholarship programs and improve the quality of education by building educational facilities. Meanwhile, CSR also provides benefits for companies in improving the company's positive image in front of the community and government, Of course, with the hope of being able to provide and increase trust which will have a positive effect on the value of the company (Nahda \& Harjito, 2011) through the sale of shares and company products, however, until now it has not been proven with certainty the effect of CSR in several studies conducted (Apriyani \& Sutjahyani, 2018; Lobo, 2016; Stacia \& Juniarti, 2015).

The COVID-19 pandemic, which is currently engulfing all countries in the world, has had a considerable effect not only on the economy, but also on public health. There are two sides that can be identified, namely:

1. With the Covid 19 pandemic, most companies in the world find it difficult to survive this crisis, with the exception of companies with certain industrial bases such as: medical equipment, medicine, telecommunications, and information technology-based companies and so on.

2. Companies with the above criteria that are able to survive have great potential in carrying out their CSR activities, meanwhile, for companies that cannot survive, of course, they will not be able to carry out CSR due to a decrease in production and profitability, even resulting in the bankruptcy of the company.

3. The Covid 19 pandemic situation can be used for companies to channel their CSR by helping in the health, economic or other sectors.

\section{CONCLUSION}

This PKM activity is carried out in order to develop and increase public knowledge (students, communities, and practitioners) about CSR which is carried out online/ virtually, attended by 147 participants. The activity gave responses to participants who were quite enthusiastic because participants often responded critically by asking various questions in response to the presentation team's presentation, as the purpose of this service activity which intends to provide added value for positive and useful knowledge for the community during the pandemic period. Contributions also provide a perspective on various activity opportunities that can be provided during the pandemic without being constrained by economic conditions, burdensome for business actors, as well as giving birth to new research ideas in the field of accounting, especially with topics that can be done during the pandemic for academics.

Thus, service activities carried out online using learning and discussion methods are expected to achieve the following three goals: (1) the public, students and practitioners can learn the knowledge conveyed in relation to the materials given in specific service activities, (2) for students to be able to develop general conceptual skills, able to learn to apply the same concept or those related to CSR or other related fields as a provision for improvement in competence, and improve competitiveness in the Industry 4.0 era, (3) develop personal abilities and attitudes that can easily be used in all practical actions (Jeannette \& Gordon, 2000).

The PKM carried out by the Team in addition to providing various positive aspects for external parties, also provided benefits for the PKM Team in sharing and increasing knowledge and experience as academics about the condition, as well as public understanding of concepts related to activities that are mandatory for the company and are the right of the community to accept them in various prescribed forms.

\section{ACKNOWLEDGE}

In the implementation of PKM activities carried out by the Team, the Team would like to express its deepest gratitude to the Chancellor of the University, Prof. Dr. Moestopo (Beragama), who has provided opportunities, support, and facilities to the PKM Team to carry out community service activities. In addition, thanks are also expressed to other universities and students who have contributed to the online service event, hopefully it will have a positive impact and knowledge and establish cooperation in the future. 


\section{REFERENCES}

Apriyani, Y. F., \& Sutjahyani, D. (2018). Pengaruh Corporate Social Responsibility Terhadap Nilai Perusahaan Dengan Profitabilitas Sebagai Variabel Moderating (Studi Empiris pada Perusahaan Manufaktur Sektor Property dan Real Estate yang terdaftar di Bursa Efek Indonesia Tahun 2011 2015 ). JEA17: Jurnal Ekonomi Akuntansi, 3(01), 69-78. https://doi.org/10.30996/jea17.v3i01.3176

Elkington, J. (1997). Cannibals with Forks : The Triple Bottom Line of 21st Century Business. Oxford.

Hardum, S. E. (2014, February). Menakertrans Minta Perusahaan Salurkan CSR Untuk Wirausaha. Berita Satu. https://www.beritasatu.com/ekonomi/168766/ menakertrans-minta-perusahaan-salurkan-csruntuk-wirausaha

Jeannette, V., \& Gordon, D. (2000). Revolusi Cara Belajar. Kaifa.

Kitzinger, J. (1999). The methodology of focusgroup interviews: the importance of interactionbetween research participants. Sociology of Healthand Illness, 16, 103-121.

Lobo, Y. P. A. (2016). Corporate Social Responsibility Terhadap Nilai Perusahaan Dengan Profitabilitas Sebagai Variabel Intervening. Jurnal Ilmu Dan Riset Akuntansi, 5(8), 607-618. https://doi.org/10.37476/ akmen.v17i4.1188
Nahda, K., \& Harjito, D. A. (2011). Pengaruh Corporate Social Responsibility Terhadap Nilai Perusahaan Dengan Profitabilitas Sebagai Variabel Moderasi. Jurnal Siasat Bisnis, 15(01). https://doi. org/10.35129/ajar.v3i02.134

Prihanto, H. (2018). Etika Bisnis dan Profesi: Sebuah Pencarian. Rajawali Pers.

Stacia, E., \& Juniarti. (2015). Pengaruh Pengungkapan Corporate Social Responsibility Terhadap Nilai Perusahaan Bumn Sektor Pertambangan. Business Accounting Review, 3(2), 81-90. https://doi. org/10.37641/jiakes.v9i1.559

Welianto, A. (2020, February). Pencemaran Lingkungan: Macam, Penyebabnya, dan Dampaknya. Kompas.Com. https://www.kompas.com/skola/ $\mathrm{read} / 2020 / 02 / 06 / 090000969 /$ pencemaranlingkungan-macam-penyebabnya-dandampaknya?page $=$ all

https://feb.unpad.ac.id/dampak-pandemi-coronaterhadap-laporan-keuangan-dan-praktik-bisnis-diindonesia/

https://www.merdeka.com/peristiwa/infografis-dampakpandemi-covid-19-terhadap-perusahaan.html 